\title{
Design and construction of a combined underground paste backfilling and surface paste storage system in Baiyinchagan Polymetallic Mine
}

\author{
Lei Guo China ENFI engineering Co Ltd, China \\ Huilai Wang China ENFI engineering Co Ltd, China \\ Xuesen Sun China ENFI engineering Co Ltd, China \\ Jiguo Zhou China ENFI engineering Co Ltd, China \\ Ximin Liang China ENFI engineering Co Ltd, China
}

\begin{abstract}
Tailings paste backfilling and surface paste storage are safe, efficient, energy-saving and environmental friendly and are thus widely recognized and applied in the mining industries of developed countries. In China, tailings paste backfilling has developed rapidly, with tailings paste backfilling systems having been established in a considerable number of mines in recent years. However, paste storage is still in its early days, with only two paste storage systems are in operation in large-scale mines in China. Baiyinchagan mine, designed by China ENFI, is in the stage of commissioning and has established the first combined paste backfilling and paste storage system in China. This paper mainly introduces the process, facilities design and construction of the system.
\end{abstract}

\section{Introduction}

Paste backfilling and paste storage are safe, efficient, energy-saving and environmental friendly and are thus widely recognized and applied in the mining industries of developed countries. In the 1990s, China ENFI had begun to research and develop paste backfilling $(Y u, 2011)$ and successively established and put into operation paste backfilling systems in Jinchuan Nickel Mine, Tonglushan Copper Mine, Huize Lead-Zinc Mine, Dongguashan Copper Mine and Chambishi Copper Mine. Compared with the rapid development of paste backfilling, paste storage is still at a preliminary stage in China, with only two paste storage systems in largescale application, namely Wunugetushan Copper and Molybdenum Mine and Baiyunebo West Mine. There are no fully developed combined disposal systems of tailing paste backfilling and paste storage in China yet. Located in Xiwuzhumuqinqi, Inner Mongolia, Baiyinchagan Polymetallic Mineis situated among hills and prairie. Polymetallic ore bodies that contain metals such as lead, zinc, silver, copper and tin have been discovered in this area. In 2014, China ENFI had completed the preliminary detailed designs for the mine and initiated the infrastructure construction. In September 2016, infrastructure construction was completed and the mine was put into trial production. The designed production rate is $5000 \mathrm{t} / \mathrm{d}$, with two processing streams composed of a $2500 \mathrm{t} / \mathrm{d}$ of Lead-Zinc system and a $2500 \mathrm{t} / \mathrm{d}$ of Copper-Tin system. The underground mine uses a main ramp development system, the sublevel open stoping and a bottom-up cut and fill method. A tailings paste underground backfilling system and surface paste storage system have been established. The 
ore is transported by trucks along the main ramp to the primary crushing system on the surface and then conveyed to the beneficiation plant. For mineral beneficiation, the lead-zinc system adopts semi-autogenous grinding and ballmill technology $(\mathrm{SAB})+$ lead-zinc selective flotation process + two-stage dewatering process; the copper-tin system adopts semi-autogenous grinding and ballmill technology $(S A B)+$ copper-lead bulk flotation + copper-lead separate flotation + zinc-sulfur bulk flotation + zinc-sulfur separate flotation+ cassiterite four-stage gravity separation + cassiterite flotation + two-stage dewatering process.

\section{Total tailings underground paste backfilling system}

With the mining area mainly covered by forest and grasslands that the local herdsmen rely on, the application of paste filling has a high requirement for the protection of ecology and environment.

The entire tailings underground paste backfilling system consists of paste preparation, transportation and stope filling. All the tailings are sent to the filling station to be prepared using a deep cone thickener and delivered to the underground working area through slurry pumps and pipelines.

Filling facilities mainly include a preparation station, backfill drilling holes and conveying pipelines. The main facilities and equipment of the preparation station include tailings thickening equipment, cement bins, cement feeding equipment, two-stage horizontal mixers and slurry pumps.

\subsection{Paste preparation and transportation}

The backfill preparation station is equipped with two deep cone thickeners and three sets of backfill slurry preparation and transportation systems, which comprise two sets of $\Phi 14 \mathrm{~m}$ deep cone thickeners, three cement bins, three micro powder scales, three biaxial-bladed mixers, three double-helix mixers, three slurry pumps and related instruments monitoring systems. Two of the deep cone thickeners simultaneously operate together with two sets of slurry preparation and transportation systems. The third set is on standby during normal production. Each set can be used for total tailings cementation as well as uncemented filling, and the quantity of water, cement and tailings can be adjusted according to the actual production conditions. The preparation capacity of each deep cone thickener is (80 to 100$) \mathrm{m}^{3} / \mathrm{h}$. The bottom of each thickener is equipped with two underflow pumps, one operating and one standby during normal production. To fulfil the expected production targets, one deep cone thickener will need both underflow pumps to operate, with the second thickener needing only one pump to operate.

The maximum delivery pressure of the pipeline is $12 \mathrm{MPa}$ when the slurry pump conveys the filling slurry to the underground working face. The paste preparation system is shown in Figure 1.

The underground backfilling system has three vertical boreholes in total, each with a diameter of $\Phi 350 \mathrm{~mm}$. Bimetal composite wear-resistant casing has been laid in each borehole, with an external diameter of 219 $\mathrm{mm}$, an inside diameter of $167 \mathrm{~mm}$ and a wall thickness $\delta$ of $26 \mathrm{~mm}$ (the thickness of wear-resistant layer is $18 \mathrm{~mm}$ ). The velocity is $1 \mathrm{~m} / \mathrm{s}$. The pipeline in the underground access way is a ceramic-lined steel composite pipe with an external diameter of $194 \mathrm{~mm}$ and a wall thickness $\delta$ of $12 \mathrm{~mm}$. The filling pipe in the stope comprises a mine resin tube whose specification matches the ceramic-lined steel composite pipe.

The underground filling system is shown in Figure 2. 


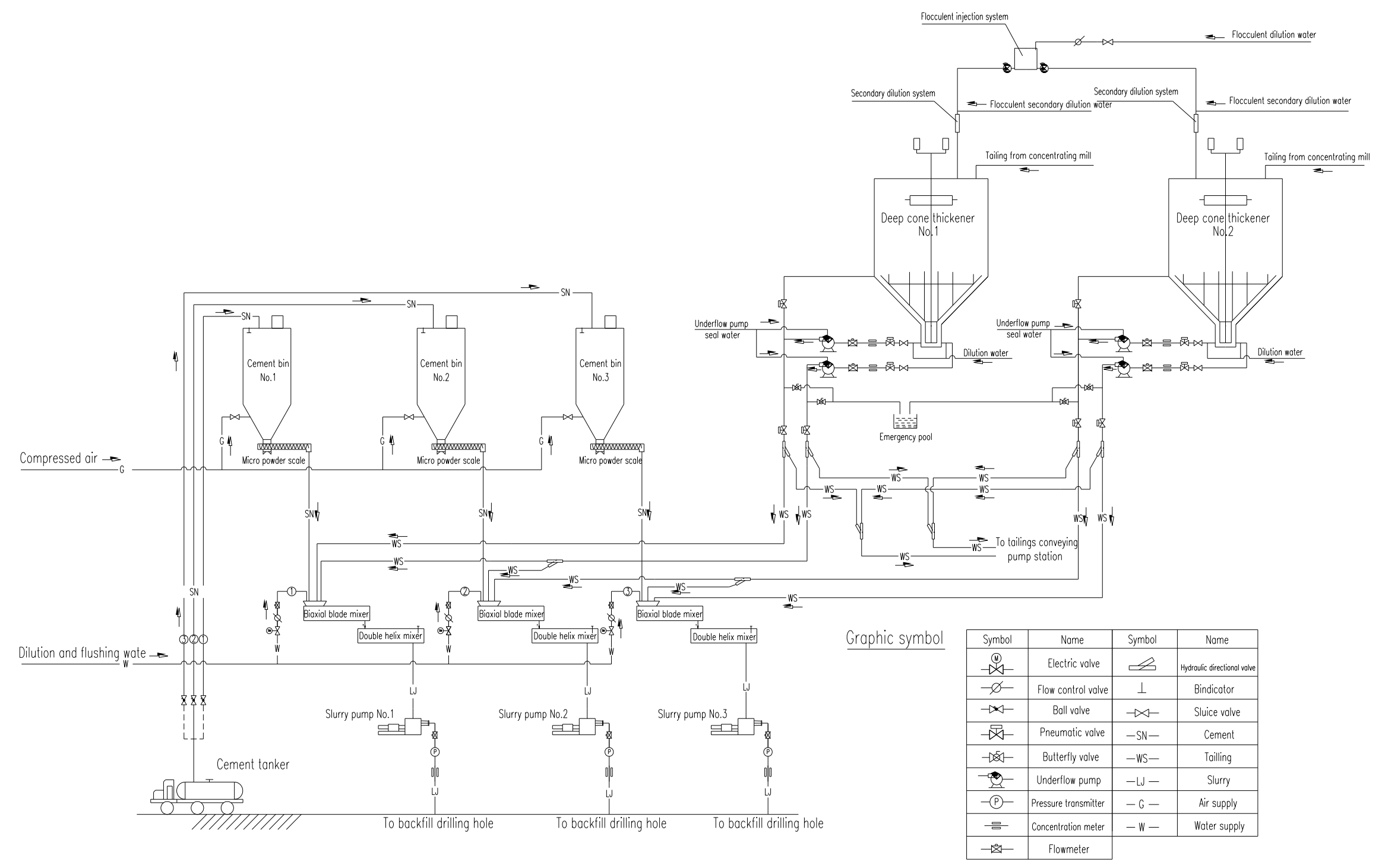

Figure 1 System diagram of paste preparation 


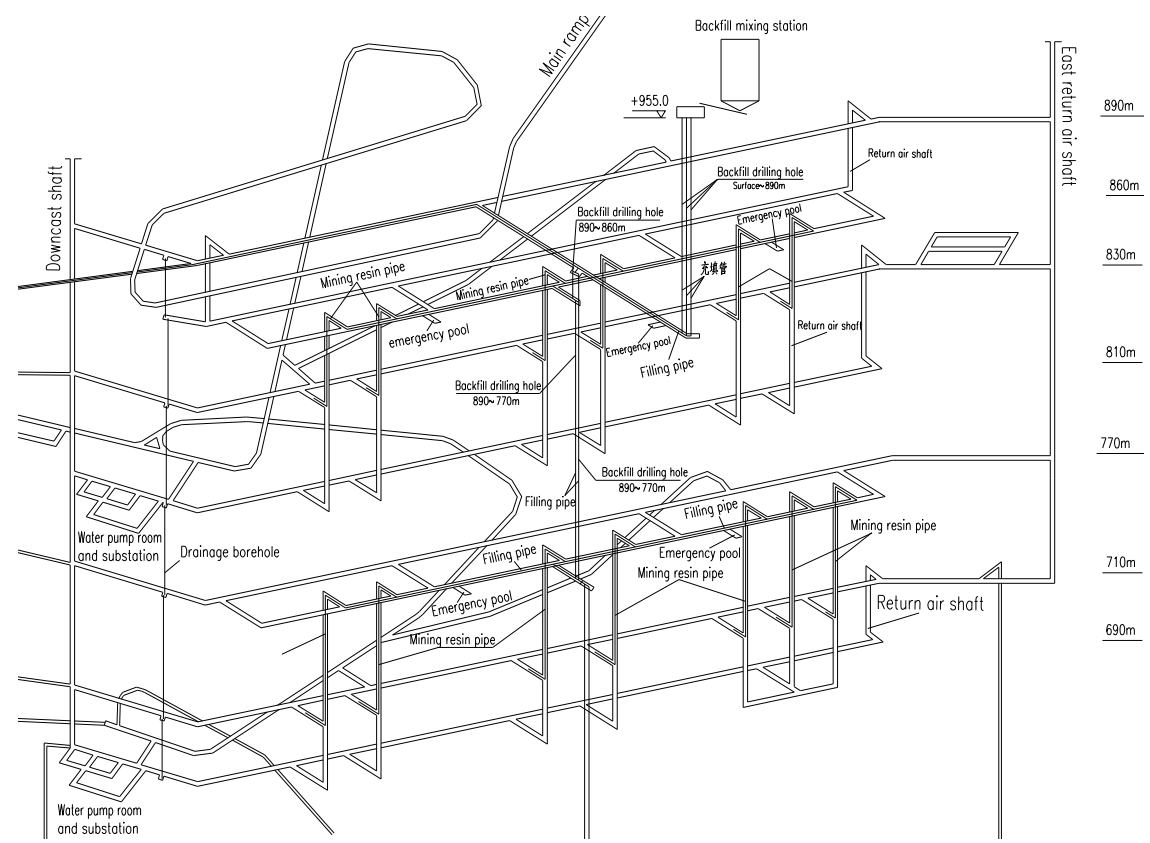

Figure 2 Diagram of the underground filling system

\subsection{Stope filling}

\subsubsection{Sublevel open stoping mining method}

After the completion of ore drawing and hauling in the stope, filling operations will be carried out. The firststage adopts the technique of full tailings consolidated filling. Approximately 4 to $6 \mathrm{~m}$ of cemented backfill are placed in separate stages at the bottom and the top of the stope with the cemented fill featuring a limesand ratio of 1:4. For the middle stope, the lime-sand ratio of the cemented fillings is 1:10. The second-stage filling is slightly different from the first one in that full tailings uncemented fill is used to backfill the middle stope. When conditions permit, waste rock excavated during production is transported to the mined-out area for filling. A schematic of sublevel open-stope with subsequent filling mining method is shown in Figure 3.

$\underline{\underline{1-1}}$

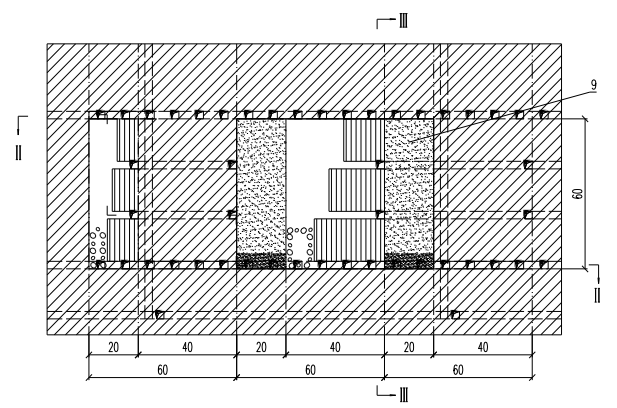

$\underline{\text { II-II }}$

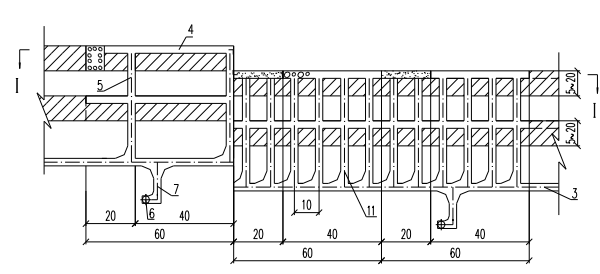

$\underline{\underline{\underline{11}}}$

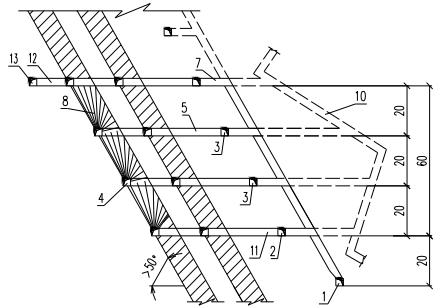

$\stackrel{\text { Graptic symbol }}{=}$

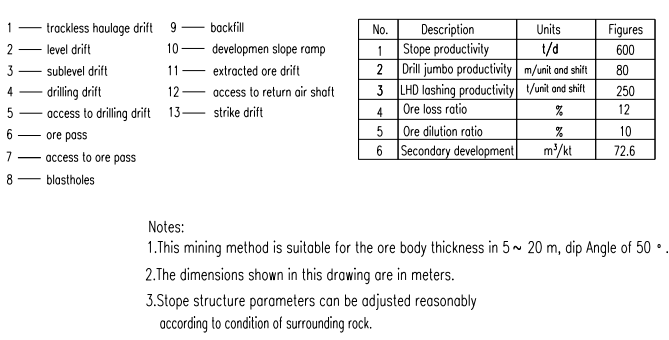

Figure 3 Schematic showing the sublevel open stoping mining method 


\subsubsection{Bottom-up cut and fill mining method}

The height of the first mining layer at each level is filled with $4 \sim 6 \mathrm{~m}$ of cemented fillings with the sand and lime ratio of 1:4. Subsequent layers are filled by $4 \mathrm{~m}$ of cemented fillings, $3.7 \mathrm{~m}$ of uncemented filling and the top $0.3 \mathrm{~m}$ is filled using cemented fill with the sand and lime ratio of 1:4. A one-meter high space on the top is reserved for blasting free face. The topmost filling layer of each level needs to be connected to the ceiling. A schematic of the upward horizontal slice stoping and backfilling mining methods is shown in Figure 4.
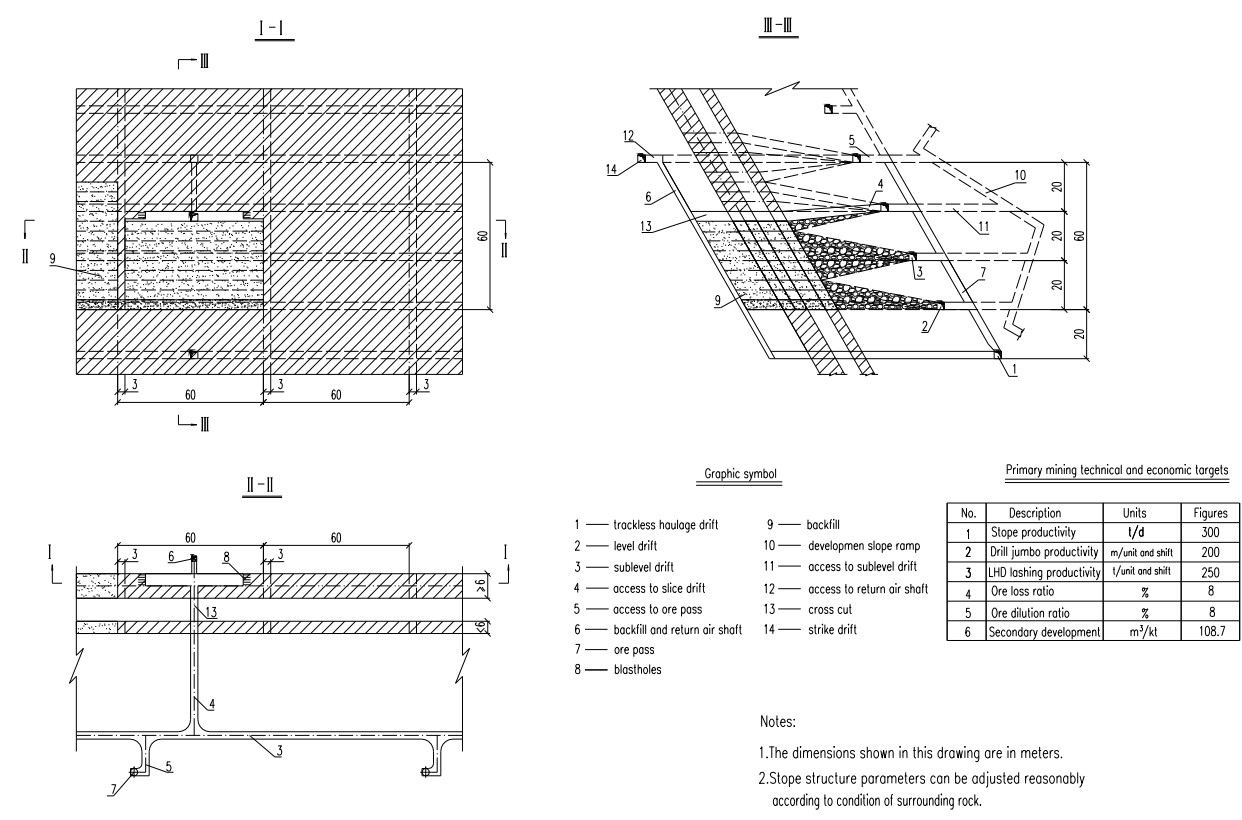

Figure 4 Bottom-up cut and fill mining method

\section{Surface paste storage system}

The dry landscape with high evaporation rates makes it suitable for the application of paste tailings stacking. The full tailings paste storage system includes paste preparation, transportation and discharge facilities. A deep cone thickener concentrates and transports the tailings slurry to the tailings storage facility (TSF) through the tailings pump station and pipelines.

\subsection{Paste preparation and transportation}

The tailings pump station includes one slurry tank equipped with an agitator, two centrifugal feed pumps (one operating and one standby) and two diaphragm pumps with frequency control. The flowrate of each diaphragm pump is $200 \mathrm{~m}^{3} / \mathrm{h}$, with a pressure of $8.0 \mathrm{MPa}$.

Two alternatively used DN200 tailings transport pipelines are set up between the tailings pump station and the TSF. Each pipeline is approximately $7000 \mathrm{~m}$ long, one being a ceramic composite pipe and the other a seamless steel pipe. The pipelines are set on the ground and covered with $10 \mathrm{~cm}$ thick polyurethane foam insulation layer and an external electric heating device. The flow chart of the paste tailings preparation and transportation process is shown in Figure 5. 


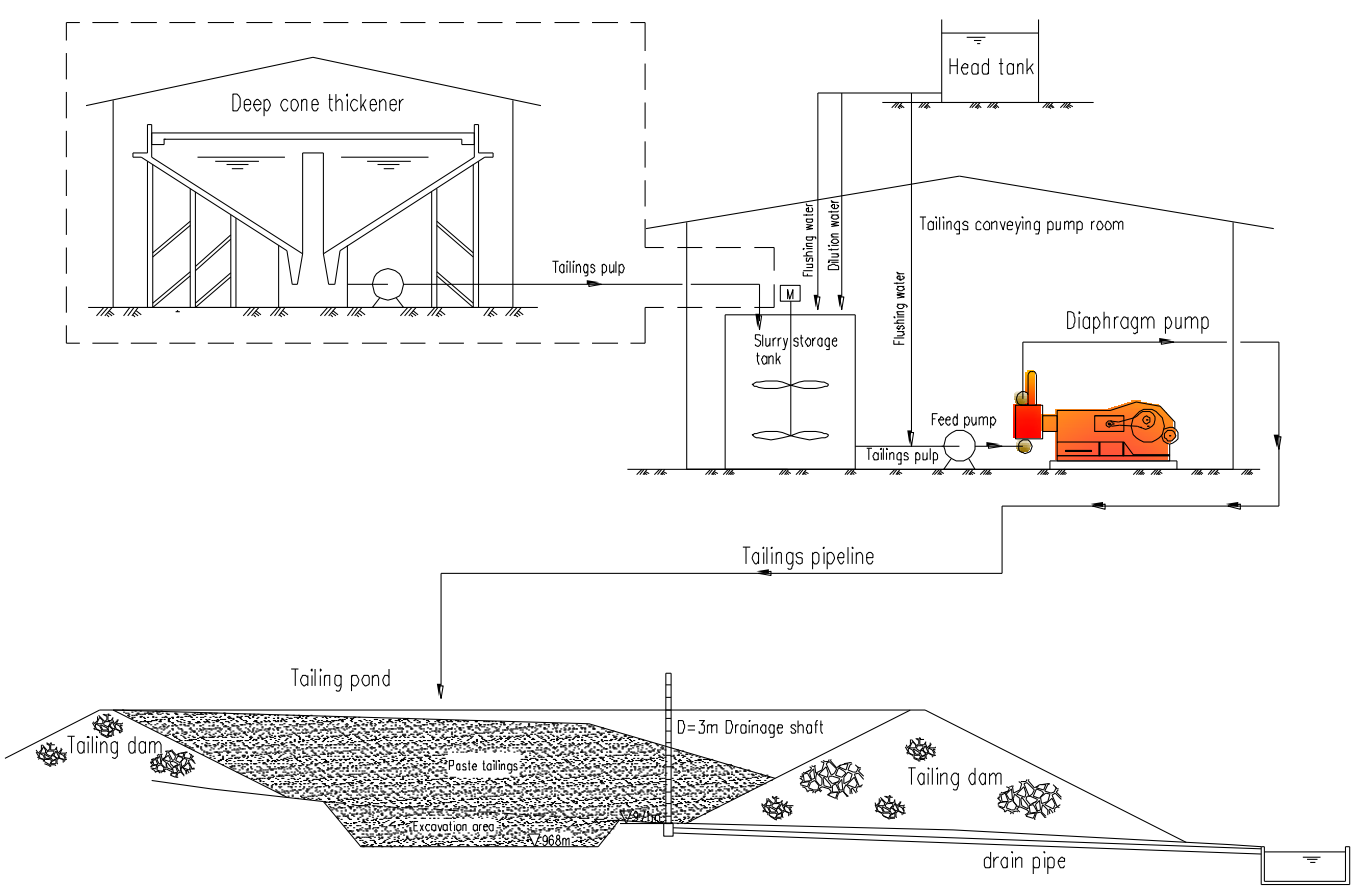

Figure 5 Flow chart of the paste tailings preparation and transportation process

\subsection{Discharge of paste tailings}

The TSF is located in the southeast valley approximately $4.3 \mathrm{~km}$ below the beneficiation plant. The layout of the TSF is shown in Figure 6. The catchment area is roughly $1.02 \mathrm{~km}^{2}$, with a total storage capacity of approximately 14.271 million $\mathrm{m}^{3}$, meeting the requirements for production lasting 20 years. The tailings pond is lined with a HDPE geomembrane to minimise seepage.

The paste tailings discharge uses point discharge around the entire facility. There are two tailings pipelines on the tailings dam, one operating and one standby. Spigot pipes are installed on the main tailings pipeline and the space between the spigots is $100 \mathrm{~m}$. The spigots are used on rotation in order to ensure the uniform increase of the tailings. 


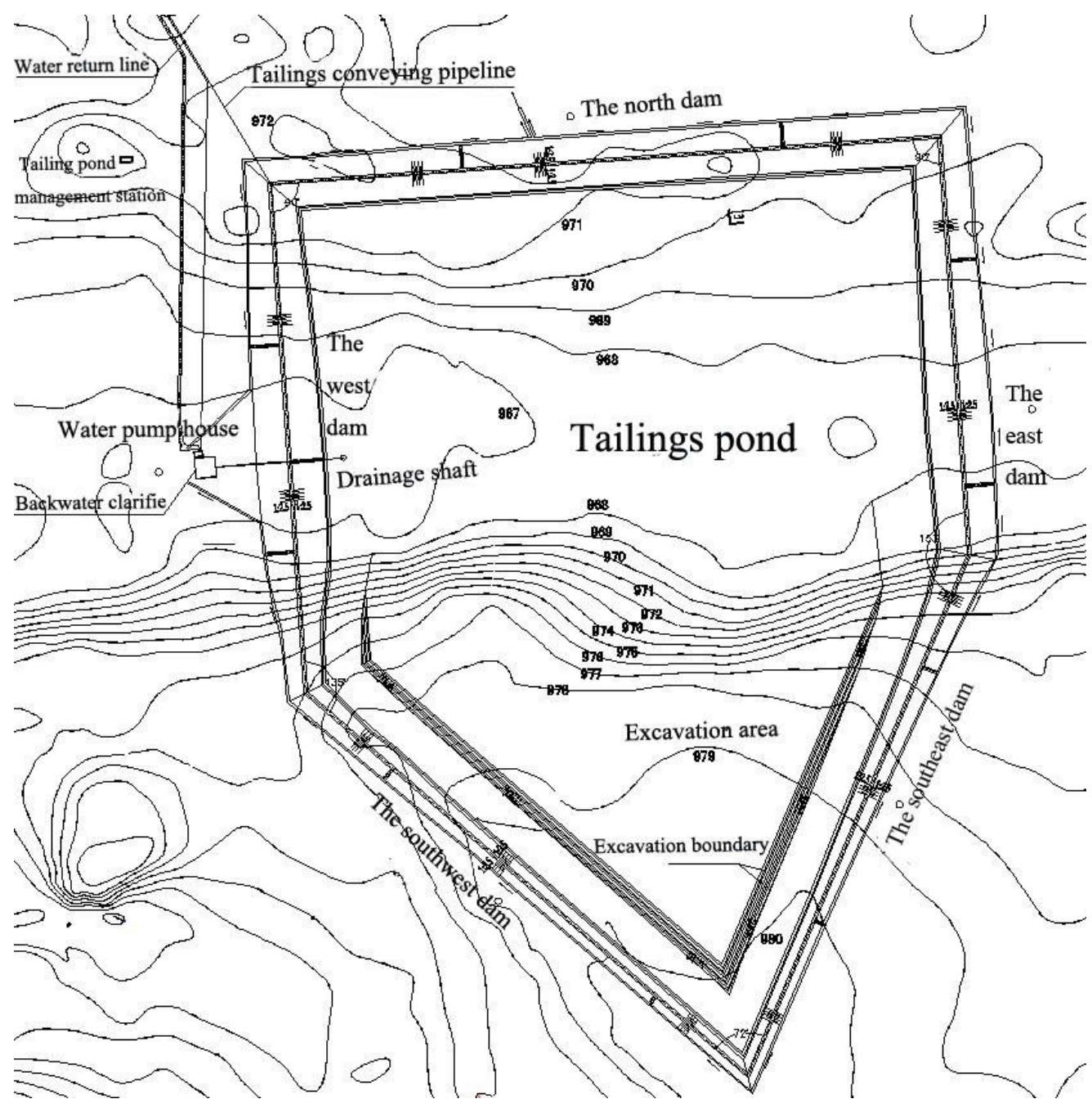

Figure 6 Layout of the TSF

\section{Combined paste tailings management system}

\subsection{Technical and economic comparison}

The tailings paste backfilling and surface storage systems have been described in detail in this paper. A technical and economic comparison of the following two schemes is described as follows.

- Option I: Independently set up paste filling system and paste stockpiling system.

- Option II: Set up paste filling and paste stockpiling united disposal system.

The comparison of the two options from an economic point of view is shown in Table 1. 


\begin{tabular}{|c|c|c|c|c|}
\hline No. & Project & Option I & Option II & $\begin{array}{c}\text { Difference } \\
\text { (I-II) }\end{array}$ \\
\hline 1 & Project overview & $\begin{array}{c}\text { Independently set paste filling } \\
\text { system and paste stockpiling system, } \\
\text { set deep cone thickeners } \\
\text { respectively }\end{array}$ & $\begin{array}{l}\text { Set paste filling and paste } \\
\text { stockpiling united disposal } \\
\text { system, share a deep cone } \\
\text { thickener }\end{array}$ & \\
\hline \multirow[t]{4}{*}{2} & Investment spending (¥) & $30,530,000$ & $12,510,000$ & $18,020,000$ \\
\hline & Construction ( $¥)$ & $14,590,000$ & $6,860,000$ & $7,730,000$ \\
\hline & Equipments purchasing ( $¥)$ & $14,110,000$ & $5,000,000$ & $9,110,000$ \\
\hline & Installation project (¥) & $1,830,000$ & 650,000 & $1,180,000$ \\
\hline 3 & $\begin{array}{l}\text { Power consumption } \\
\qquad(\mathrm{kWh} / \mathrm{a})\end{array}$ & $3,450,000$ & $3,760,000$ & $-310,000$ \\
\hline \multirow[t]{3}{*}{4} & Operating cost ( $¥)$ & $2,750,000$ & $2,230,000$ & 520,000 \\
\hline & Electric charge $(¥)$ & $1,660,000$ & $1,810,000$ & $-150,000$ \\
\hline & Maintenance cost (¥) & $1,090,000$ & 42,000 & 670,000 \\
\hline 5 & Service life period(a) & 30 & 30 & \\
\hline 6 & $P C(I=10 \%)$ & $56,430,000$ & $33,490,000$ & $22,940,000$ \\
\hline
\end{tabular}

In comparing the two options, it is evident that option II has significant economic advantages by saving an investment worth 2,618,306 USD and operating costs worth 75,556 USD. The net present cost for option I is $8,199,279$ million USD and for option II is 4,866,097 USD.

It is obvious that because of less investment, lower operating costs and lower present cost, Option II was selected.

\subsection{System description}

All the tailings produced by the concentrator are sent to a single station and the tailings slurry are processed by the deep cone thickeners. Once its concentration meets the requirement, the slurry is sent to the underground working area via the slurry pumps. When the filling operation is completed, the slurry is diverted to the slurry storage tanks in the conveying pump station, and then pumped to TSF through the diaphragm pumps and pipelines. A schematic of the full tailings paste united disposal system is shown in Figure 7. 


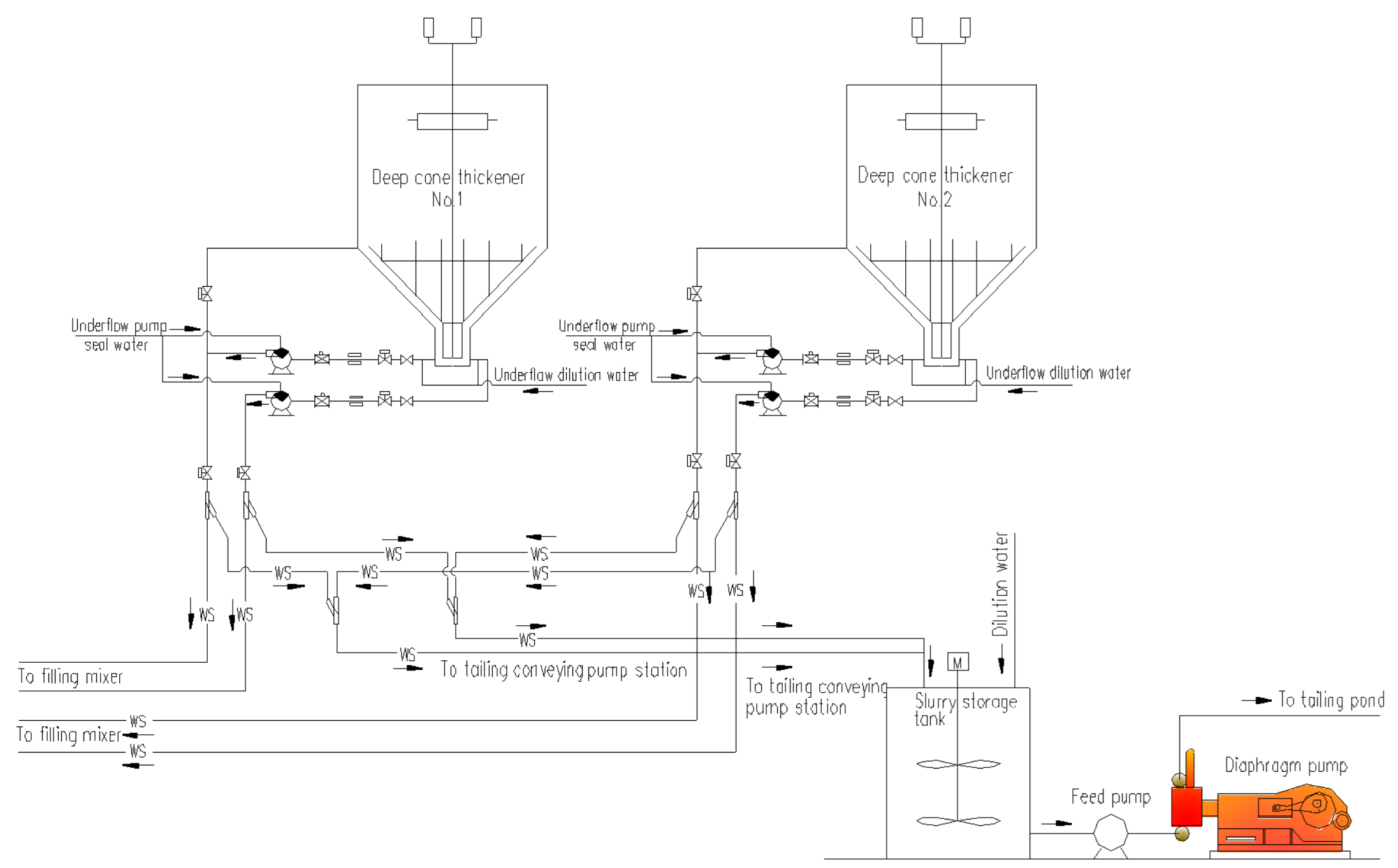

Figure 7 Schematic of the full tailings paste united disposal system 


\subsection{System construction situation}

The construction of filling station and tailings pumping station was launched in 2015 and was completed in September 2016.

At present, the mine has not yet been officially put into production and no mined-out areas are available for testing the paste filling system, but field engineers have already completed the de-bottlenecking on the paste backfilling system and the paste storage system.

The particle size distribution of the tailings produced by the beneficiation plant is shown in Table 2 .

Table 2 Tailings particle size analysis

\begin{tabular}{cccccc}
\hline Particle size(mesh) & 400 & 325 & 200 & 100 & Other \\
Content(\%) & 50.7 & 17.7 & 13.4 & 7.8 & 10.4 \\
\hline
\end{tabular}

The concentration of the slurry from the bottom of the deep cone thickener is $55 \sim 61 \%$, and when the underflow concentration reaches $61 \%$, the tailings slurry form a paste (as shown in Figure 8). Photographs of the system are shown in Figures 9 12. Figure 13 shows the discharge onto TSF.

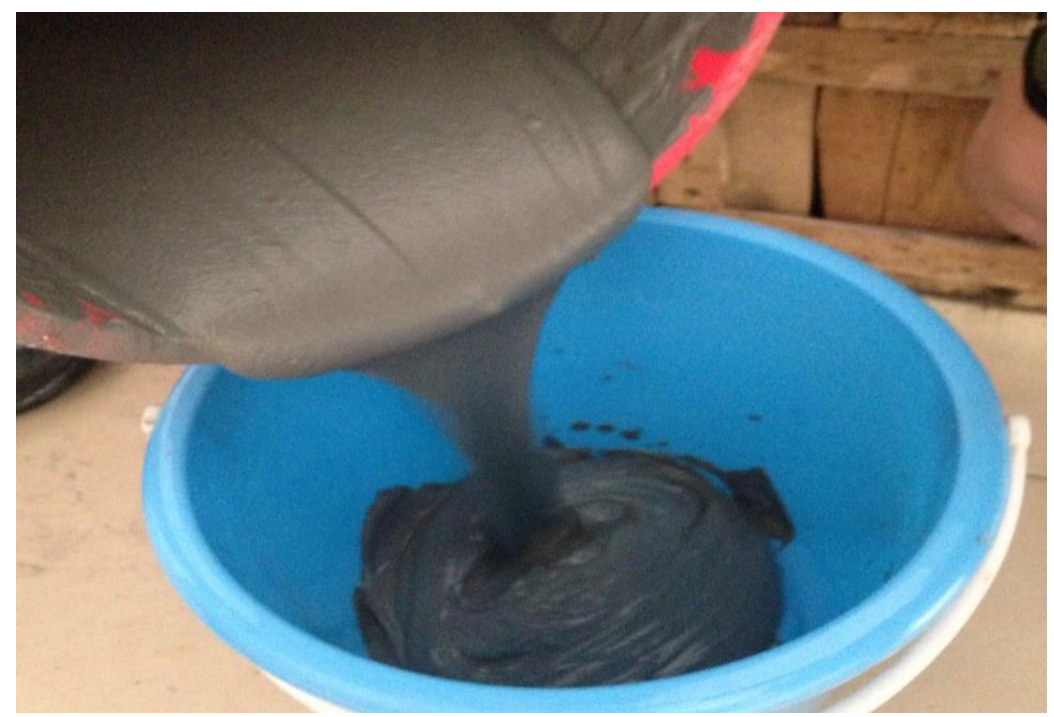

Figure 8 The state of slurry when underflow concentration reach $61 \%$

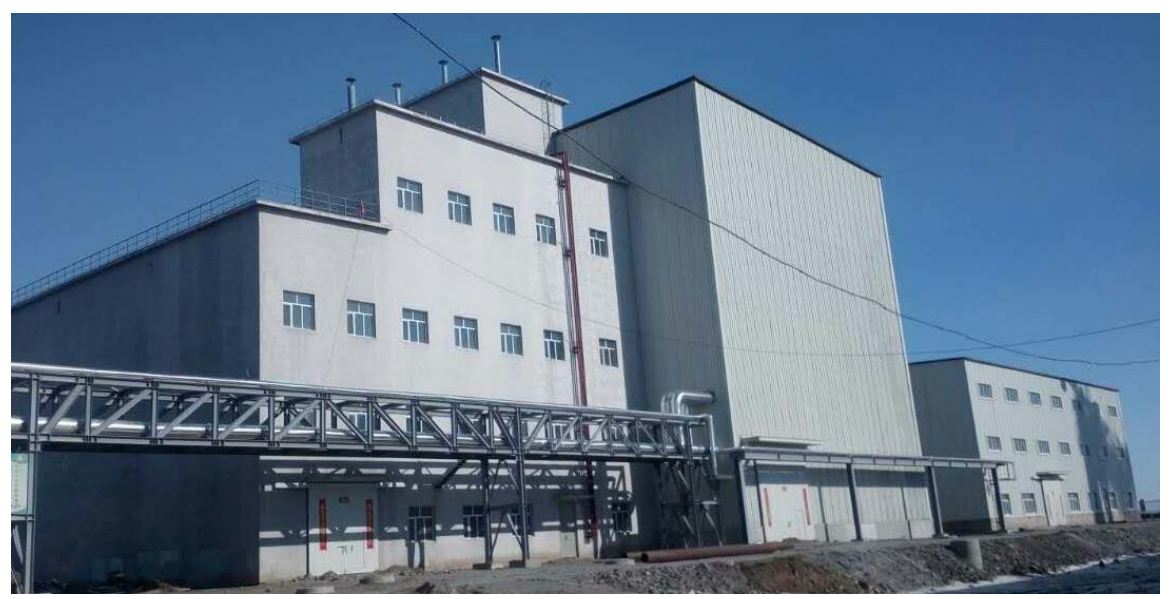

Figure 9 Outside view of the filling station and tailings conveying pump station 


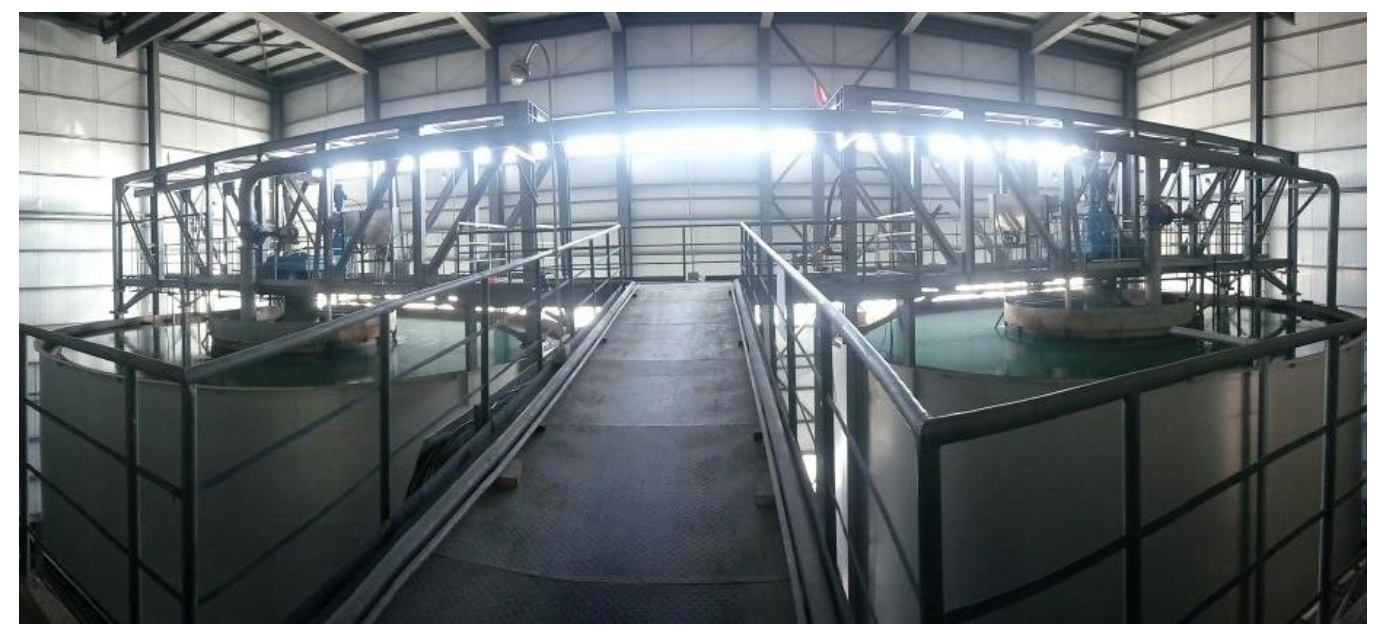

Figure 10 The upper figure of deep-cone thickener (flat view)

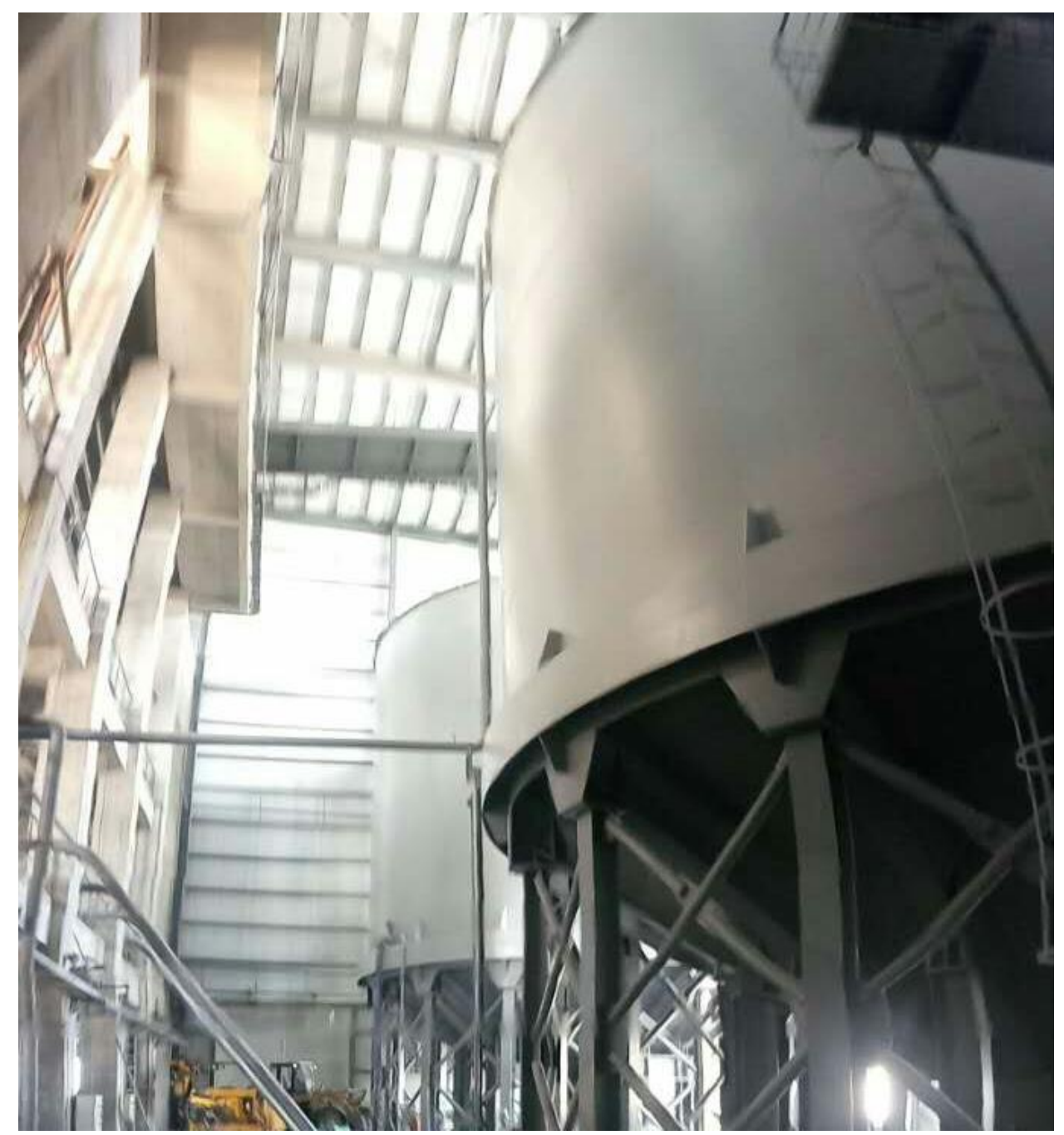

Figure 11 The overview of deep-cone thickener(upward view) 


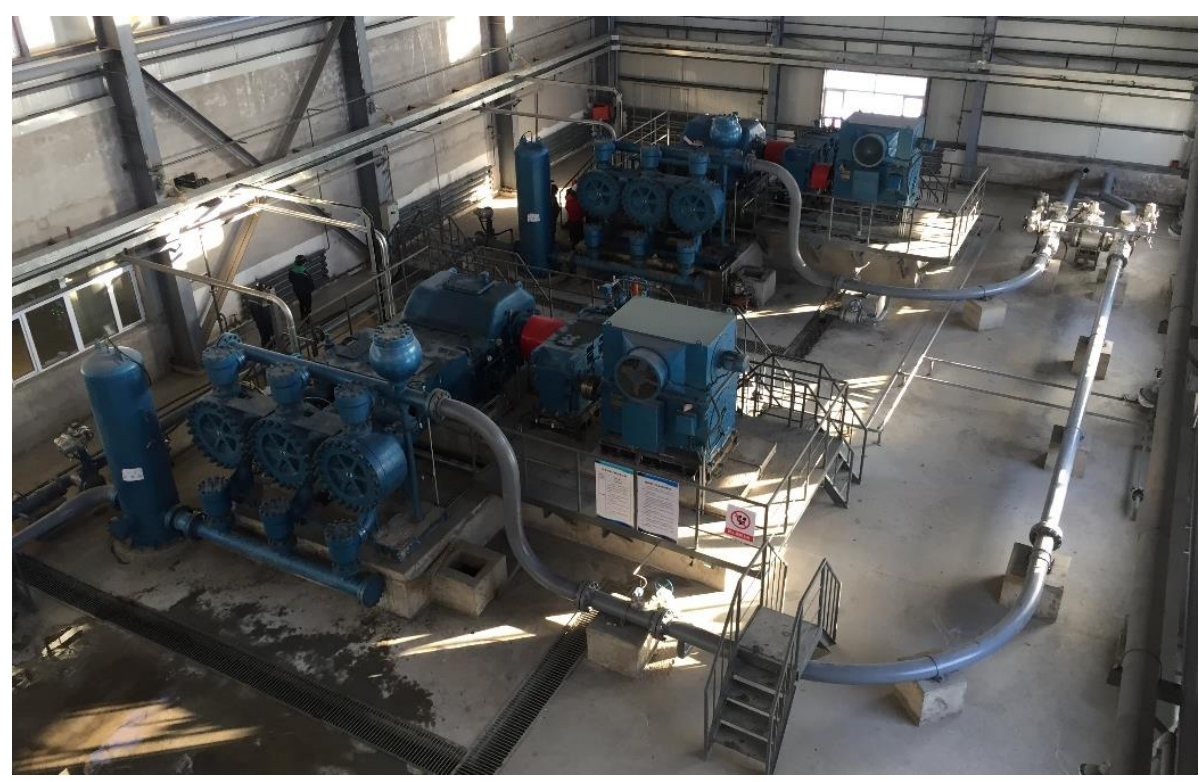

Figure 12 Interior view of tailings conveying pump station

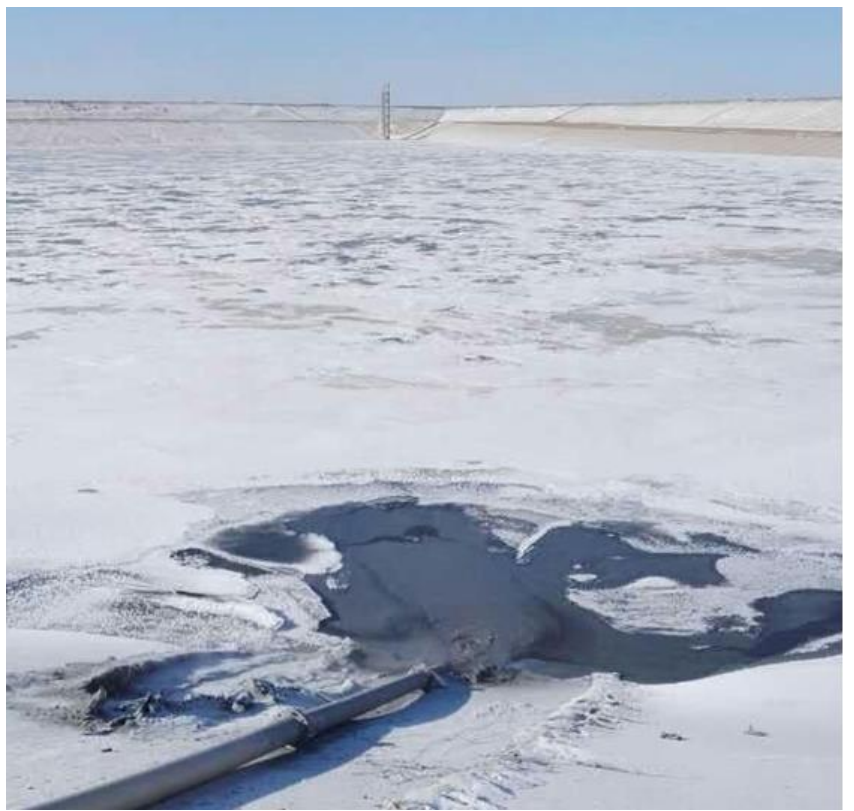

Figure 13 The tailings pond

\section{$5 \quad$ Conclusions}

China ENFI has innovatively designed a combined underground tailings paste backfilling and surface paste storage system in the Baiyinchagan Mine. After one and a half years of constructing, the total tailings paste system has been completed and the trial operation shows its feasibility in design and reliability in application. The successful application of the combined surface and underground paste system in Baiyinchagan mine makes this a viable option for many other mines evaluating the design and construction of paste backfilling and pasting storage systems.

\section{References}

Yu, R. 2011, 'Innovation achievements of backfill technology in China and remaining to be further research issues in the future', Mining Technology, vol. 11, pp. 1-3 